\title{
Study on the Subjectivity of Students in English Teaching
}

\author{
Yanqing Ge \\ Foreign Language Teaching Department, Yantai Nanshan University, Yantai, China \\ Email: dreamingdove@163.com
}

Received 31 May 2016; accepted 20 June 2016; published 24 June 2016

Copyright (C) 2016 by author and OALib.

This work is licensed under the Creative Commons Attribution International License (CC BY). http://creativecommons.org/licenses/by/4.0/

(c) $\underset{\mathrm{EY}}{\text { (i) }}$ Open Access

\section{Abstract}

In modern educational fields, the quality education is put more weight, which aims to reduce the heavy homework burden of students and enhance the quality of students and the mass of education. Some theories, such as the constructivism learning theory and cognition education, are put forward and used fully. In the reform, the Dulangkou Middle School has created a unique teaching mode. The impact of the mode is very extensive, and it upsurges the thinking for subjectivity education and subjectivity learning strategies. The theses, at first, state some concepts, such as the subjectivity education and the subjectivity learning strategy, and survey and analyze the problems in the traditional English classroom teaching, and then analyze the teaching mode of Dulangkou. Through contrasting and analyzing the problems in the traditional English classroom teaching and creative methods of Dulangkou, some knowledge about the meaning of developing the subjectivity of students is put forward to further explore how to develop the subjectivity of students.

\section{Keywords}

Subjectivity, Subjectivity Education, Subjectivity Learning Strategy, Mode of Dulangkou

Subject Areas: Education, Linguistics

\section{Introduction}

A fundamental assumption that governs the study of English and the study preparation of English teachers is that "the subject of English is always the site of subjectivity" [1]. As used here, subjectivity refers to the process of the production or the making of the "thinking, speaking, acting, doing or writing agent" [2], that is, the human subject. Here, it is necessary to emphasize both process and production, as these claims about human subjectivity make the work of teaching English possible. Human subjectivity, who and what we are, is produced through, among other things, our life experiences and how we understand these experiences, an ongoing process in which change is both possible and real. It can be argued that the study and teaching of English accelerate and accen- 
tuate this process, actively encouraging the production of certain kinds of subjectivities [3].

But, at present, some methods of English teaching hinder the full implementation and the operation of the quality education. The basic spirit of the quality education contains three factors: full development, the capability of innovation and long-life learning. The purpose of English classroom teaching is to carry out the quality education, reflecting the idea of people-centered education. Training the interest and attitude of learning is in the first place of English teaching. As a teacher, he or she should think of developing the learning strategy and the personality of students as an important component of teaching. Rumsfeld said that knowledge is not a passive absorption, but is developed in condition of learners constructing positively. The characteristics of study in constructivism learning theory are a positive study. In other words, constructive learning is the intrinsically motivated learning, which is the learners' curiosity, strong thirst for the knowledge [4]. Based on the above mentioned theory, it is a researchable problem how to enhance the students' subjectivity in the course of English teaching and develop the capability of students under the guidance of a new education concept.

Meanwhile, in recent years, with the globalization of economics and the development of culture, language learning has become more and more important to the people in the world, while studying the optimal way of teaching and learning English has been necessary and indispensable. The students nowadays must be cultivated into lifelong learners to adjust themselves to the limes of knowledge explosion. Therefore, the subjectivity of students is becoming more and more important in learning. And the best way of learning and teaching English could help learners to foster the ability of learning autonomy. Which is the best way? It is necessary and helpful to establish a students-centered language learning environment in classroom teaching. And the students-centered language teaching model which can effectively develop the subjectivity of subjectivity of students is becoming more and more important in learning.

Due to the influence of traditional education, English teachers are often keen to take "duck-stuffing" type of teaching in the teaching of English, forming a condition that teachers speak, students listen; teachers write, students copy; teachers exam, students cite. Students are in the passive position. It is difficult to improve the ability of listening, speaking, reading and writing of students. Therefore, it will not be able to meet the requirement of quality education and the inspecting trends of focusing on the ability in exams. To adjust the teaching of English to meet the requirement of the social modernization and the development of the communicative ability in English and enable students to obtain self-learning ability, teachers must promote the all-round development of students, namely how to promote the development of subjectivity of students. The majority of teachers are taking effort to explore the subjectivity of students. Therefore, in the teaching of English not only do teachers teach students knowledge but also cultivate the students' skills, what is more important, teachers should teach students to "learn to do", "learn to live together", "learn to be", that is what we must focus on human development and create better conditions in class to play the subjectivity of students and enhance the effect of teaching.

To discuss the teaching method, some concepts are introduced to help readers to understand the subjectivity of students in teaching in this paper. Based on it, the condition of English teaching in middle school is surveyed and studied from the view of students and teachers; it concludes that if the method of teachers can not stimulate interest of students, the ability of students do not be fully showed, and it can not improve the full development of students. Based on the problems that are found in survey, through the analyzing the mode of Dulangkou, it is a creative teaching strategy, because it contains many some new theory and methods, especially pay attention to the subjectivity of students. Through contrasting and analyzing the problems of middle school and creative methods of Dulangkou, some advices to develop the subjectivity of students are put forward.

\section{Literature Review of Subjectivity in English Teaching}

\subsection{The Subjectivity}

The subjectivity is how to deal with the relationship between the subject and the object. Marx said: "Subjectivity is the most essential attribute." The subjectivity in education is the initiative, in which students actively involve themselves to teaching activities under the guidance of teachers. Lightbown [5] summarize the subjectivity with the autonomy, the initiative and the creativity. Autonomy, which focuses on the independent rights of the subject, is the performance of the subject's possession and control of activities; the initiative, which focuses on the possibility of the subject, is the performance of the conscious choice of the subject about activities and participation of activities; the creativity, which focuses on the use of knowledge in practice, is the concentrated performance 
of independent autonomy and the initiative, and is the highest step of the subjectivity. The development of subjectivity of students should be paid more attention in the modern open society. Teachers should fully understand students and help them to develop the subjectivity of students. Relative to adults, middle students are weak in the sense of a subject and the ability to deal with the relation between the subject and the object. What is more, the subjectivity of students needs training, guiding and enhancing. It is the responsibility of teachers to promote the development of students. So teachers should have the most essential attribute to implement the quality education in classroom teaching and improve the quality of students. Teachers should promote the development of students in the teaching of English, which is the main channel of enhancing the subjectivity of students.

\subsection{The Subjectivity Education}

The subjective education, simply speaking, means that students are the main role of learning activities in the process of teaching, and it can dynamically develop the individual potentials of students [6]. Students are the center of teaching English, therefore teaching methods and teaching materials should be arranged according to the learning of students. The teacher should guide the students to take part in the teaching as the main role instead of the person of passively getting knowledge. In the process of teaching, the teacher should use the different methods because they are different in the characteristic, ability and knowledge of students and so on. Students should be perceived as the main role learning activities, because it is the internal contradictions of students that affect the development of knowledge, ability and individual character. Although the teaching content, teaching methods and teaching equipment are very important for students, the external factors are very good; the internal factors play the most important role after all. However, the teacher is wise and cannot substitute the students. There is an old English proverb saying: "you can take a horse to the water, but you cannot make it drink." This is a clear evidence in support of the truth. Therefore, the cultivation and development of the subjectivity of students is the main problem of subjectivity education.

\subsection{The Subjectivity Learning Strategies}

The so-called subjectivity learning strategy is based on the individual learning strategies, which are changed according to different learners. It is conductive to develop the subjectivity of students. When learners choose, use and form the learning strategy, they can develop their subjectivity, choose and use a learning strategy which can make them use the most appropriate method according to the characteristic of the task of learning and their own condition, and timely adjust methods of learning to solve problems in the different conditions, which is called the subjective study learning strategy [7]. The subjective learning strategy of English is an open and dynamic concept. To a concrete English learning strategy, we cannot say that it "is" or "isn't" the subjective learning. We can only judge according to a particular study scene of a concrete learner, if it can play fully the subjectivity of the learner and complete effectively the task, it is concerned as the English subjective learning strategy for the learner in this time.

\section{The Situation of Traditional English Teaching and Learning}

English is a very important curriculum, the final purpose of learning English is using it to communicate, so students should be considered as the main role in learning activities. To understand the current situation of learning English for students and make an analysis of the cause why student can take different effect in study and to explore new methods of teaching, a survey is carried out to find the problem to solve. The survey contains four aspects: the pre-class of students, the situation of the ways of attending lectures, the condition of student participating in class activities, the views about the classroom teaching methods from students. Some points can be concluded: all most of students cannot preview and prepare before class; the ways of attending lectures is very unitary; a large number of students are right in the objective and the concept of learning and don't positively participating in class activities; a lots of students think cramming method of teaching is boring.

Although there are all kinds of differences in the mental and physical growth of students, intellectual development, and personality characteristics, they are eager to get knowledge. What is more, the students in middle school period should master basic language and acquire basic communicative skills for real communication. Therefore, some methods should be explored to let the students actively participate in various activities in the classroom teaching. In order to meet the goal, teachers should give full attention to the subjectivity of students in 
their language classroom as much as possible rather than purely teaching the language knowledge. To solve the problems that exist in the process of preparation of students and the condition of listening lessons and the teaching, some positive and helpful teaching methods, which can explore the potential language ability of students and evoke the students' interest to use the language creatively, should be explored and developed. Therefore, students-centered language teaching is put forward in the English Curriculum Criterion. The students-centered language teaching is the effective means currently available, and it can help to promote the learners' subjectivity and provide access to self learning and independent learning, fostering the learners' autonomy is one of the most important goals in language teaching [8].

In the last 20 years, the subjectivity of learner in language learning has been a hot topic of widespread discussion in the west. It is also very popular and important in the field of English teaching in China. Studentscentered language teaching has been widely introduced and exploited in English classrooms. To help learners to develop their subjectivity, the duty of English education which the Chinese Ministry of education has required, is to stimulate and foster the students' interest in learning, help them build up their self-confidence, cultivate a good learning habit, develop their self-access ability and form their own effective learning strategies. In order to help the learners develop a lifelong mode of learning, many authors [9] have described the subjectivity education can meet the requirement of quality education, and a teacher should pay full attention to use the subjectivity of students. But it is difficult to how to carry out the subjectivity education. Next, it will analyze the teaching mode of Dulangkou, which has got great achievement in teaching reform and then find out how to solve the problems in the survey and analyze the characteristic of the mode of Dulangkou to find how to fully develop ability of students.

\section{The Teaching Mode of Dulangkou Middle School}

\subsection{The Mode of Dulangkou}

From 1998 on, Dulangkou middle school has began the teaching reform called "taking students back to the classroom", which has a great effect in education. It makes Dulangkou middle school step to the first three from the bottom of 23 secondary schools in the county. Therefore, having a preliminary exploration about the mode of Dulangkou teaching is inevitably helpful and irradiative for English teaching and learning.

In the mode, all classes are carried out through the progress of preparing before class and exchanging, setting objectives, classifying and coordinating, showing and upgrading, consolidating and measuring. Students are divided into six groups in each class, they completed the study independently. Every new lessen is divided into three steps: preparing before class, showing and feedback. They set goals in preparing before class, exchange their own results of study in showing and test the objectives of learning in feedback. Teachers only encourage and guide them and answer doubts in short time. The students are the subject of learning; they learn not as a student but as a teacher. It is by virtue of this approach, Dulangkou middle school jumped to the first three from the bottom in eighty years. Therefore, the learning of classification and " $10+35$ " have been called the mode of Dulangkou by some education experts. As we see, it is without doubt that it is a better way to teaching.

\subsection{The Solution to Problems in the Survey}

It is put a very important place to prepare before class and discuss by groups and participate in teaching from students. They are given enough time to do these tasks, the teacher spend a little time in speaking. In the mode, the preparation before class is a procedure of English teaching; it pays attention to the characteristic of English teaching, let students exploit the questions and use English in exchanging and give students enough time to prepare and help them to find difficult points. Meanwhile, the whole class likes an activity ground, students have their own tasks and can exchange happily. They fully take part in the teaching. In the teaching, the teacher does not use the advanced media to teach, but the whole class environment stimulates the interest of students, they learn in the course of playing. They can choose the method of teaching by themselves. The mode of studentscentered teaching solves the problems that we find in the survey, which is about the traditional English teaching in china.

In the mode, the teachers used many approaches to build up students' confidence and use many strategies to develop their language competence. Students will be more responsible for their learning by identifying the goals, deciding content and choosing learning strategies. In the classroom activities of subjectivity learning model, 
students become the center of teaching and learning, teachers play the role of a director, promoter, and counselor. The result has proved that the subjective learning model is in accordance with the demand of learning of students. Therefore it should be advocated in teaching.

Meanwhile, there is a saying "the end product of education is an independent learner." McDevitt [10] has said that cultivating the learner's independence should be regarded as the end goal that teachers or educators try to pursue. The mode of Dulangkou is indicating the concept, and it offers students opportunities to explore and practice using language effectively and taking part in the activities of teaching. Students are highly motivated to learn, and the student plans, monitors, evaluates and regulates his task when learning. The teacher only arouses the students' interest, boosts the students' motivation for English learning. So it is very necessary and significant in developing students' subjectivity of learning, especially in English classroom. The mode of Dulangkou can not only solve problems that we find but also have other characteristic that is helpful to fully develop the ability of autonomous of students and encourage the interest of learning of students.

\subsection{The Other Characteristics of Teaching That Are Helpful to Develop Subjectivity of Students}

The new characteristic of teaching in mode of Dulangkou is not only helpful to solve problems but also to initiate new thinking about the method of teaching, especially the subjectivity education. Meanwhile, teaching English by activities sufficiently creates a comfortable atmosphere in the classroom.

Clearly, Dulangkou Middle School makes full of the game theory and project classification theory and fully stimulate the enthusiasm of students. Students are the participant and leader from beginning to the end in the entire classroom. They are the masters of learning, and have a strong motivation to actively engage in various activities. Each student must speak some points of knowledge, some are new, and some are old. Students can basically act as a "competent teacher". The teacher only needs to replenish the knowledge which students don't speak or leak, and makes a summary at last. It not only plays the leading role of a teacher, but also stimulates the subjectivity of students in the process of learning. It always adheres to the "student-centered, teacher-led" principle.

Teachers pay important attention to the feelings of students and create a comfortable and relaxed atmosphere. The whole school is like a big family. Even if he or she is the headmaster, she or he will give a lesson to students. They fully respect the personality and freedom of students. The teacher encourages students as a friend, enabling students to eliminate the tension and binding. Students can actively participate in teaching and fully play their subjectivity. The education mode of Dulangkou has got brilliant achievements, but it lets us think about the mode of education again.

\section{Some Suggestions on How to Develop the Subjectivity of Students in ET}

\subsection{Teachers Should Constantly Improve Their Knowledge and Update Their Teaching Concepts}

Teachers should regard the teaching of English as an important part of carrying out the quality education and educate students with overall development concept. When teaching students knowledge, teachers must train their ability for their lives, which requires teachers to further renew the idea of education and change some ideas about the fundamental task of education. Teaching language is only "learning to know". Cultivating the ability to use the language of students is also only "learning to do". "Learning to live together" and "learning to be" are more important goals of education.

Meanwhile, teachers should fully play the leading role in the teaching and should transmit teaching-center to learning-center and combine teaching and learning well. Regarding the basic spirit of learning-center is to enable students to love learning, to learn how to learn and develop good habits of study, fully reflecting the subjectivity of students. So teachers should do things as following: teachers should transfer more responsibility to the learners in the whole learning process, and ask learners to set learning goals for themselves, to design plans to achieve the learning goals, to monitor their own learning behavior, to assess their own learning and performance or their peers; teachers should give learners more instruction of learning strategy and train students to use these strategies which will help learners to transfer the strategies to new tasks and solve the new problems on their own; learners and teachers should prepare themselves for self-regulation and develop their self-regulated learning. 


\subsection{Strengthening the Subjectivity Sense of Students}

Students are the subject of learning. It emphasized that teachers should respect and develop the subjectivity sense of students and the initiative of students, and make them become the masters of learning and regard their own as the subject. In other authors' survey, the main factors of influencing the learning of foreign language: Motivation: 33\%; capability: 33\%; mental: $20 \%$; the other: $14 \%$. So teachers should help students to establish a clear motivation, and let every student realize that they are "I" and "me", enhancing the sense of subjectivity and the development of thinking independently. First, the teacher should come into class with high emotion, giving students a comfortable mood. The teacher should confidante with students; shorten the distance between teachers and students. When students make errors in pronunciation and spelling, use the wrong sentences and are very fearful and shy to speak, teachers should understand and guide, encourage and keep them learning by themselves to increase the confidence of success, instead of complaining that they are stupid and are wasting time.

\subsection{Carefully Designing Subjectivity Activities}

The teaching of English is shown by the communicative activity. The subjectivity of students is demonstrated through involving students in activities. For example, let students make cards, complete the homework independently and answer problems or read books. if having complete instantly, she or he should be given the opportunity of showing. There are different requirement about the different students. In addition, it is a gradual process from fostering the sense of communication to taking part in communicative activities and has an interaction, and the activity is the key point of creating a new condition of English teaching.

Students participate in various practical activities which can develop their subjectivity, because activities are the intermediary of subjectivity. The purpose of autonomous practice is to pursuing creativity. Students should take part in more communicative activities such as Sharon English, English Corner, and sending English emails etc. The researchable study provides wide space for the development of the subjectivity of students. They learn not only the knowledge but also the way of learning language, which is shown in the mode of Dulangkou. In a word, the subjectivity of students can be developed through an open social environment.

\section{Conclusions}

In the history of the language teaching in China, teaching English, as foreign language, has two fundamental approaches: "The first is the communicative approach with the principle requirement of learning language for communication and in communication." [11] "The second proceeds from the ideas of humanistic, democratic pedagogy, placing learners and their learning into the focus of teaching; this approach has been called the learner-centered one in EFL. Its development has brought about the notion of learner autonomy in learning.” [12] As "learner subjectivity is essentially a matter of the learner's psychological reaction to the process and content of learning.” [13] Reviewing the previous methods or foreign language teaching, it has experienced a lot of change such as Silent Way, Natural Approach, Grammar Translation Method, Situational Method, Cognitive Approach, Functional approach, Total Physical Response, Communicative Approach and so on. Awareness-raising and skills-inhaling exercises help provide students with opportunities to monitor the difficulty level of language input. The students improve their learning and develop more student-centered pedagogical approaches. A large body of studies has proved that effective language learning should be learner-centered, and research indicates the necessity of moving from teacher dependence towards learner dependence. For foreign language teachers, it is our duty to teach them English well, and it is also our responsibility to teach them how to learn it well. So in this paper, our focus is mainly on developing appropriate autonomous learning models. It is proved that it is a good way to reach the goal to develop the subjectivity of students.

There is a proverb: "If you give a man a fish, you feed him for a day. If you teach a man to fish, you feed him for a lifetime." It means that learners at school should be equipped with an ability to take charge of their own learning, and furnished with an ability to do things independently so that they can take active control of their own professional and personal development when they enter the society. Therefore, more and more teachers realize that it is an urgent task in the field of education to foster the autonomous learning ability, and make full use of the subjectivity of students. Teachers cannot teach everything, so learning English mainly depends on students, not on teachers. By analysis, we can build favorable teaching environment to help students develop their learning ability. This is not only necessary but also feasible. 


\section{References}

[1] Humm, M. (1989) Subjects in English: Autobiography, Women and Education. In: Thompson, A. and Wilcox, H., Eds., Teaching Women: Feminism and English Studies, Manchester University Press, Manchester, 39-49.

[2] Kristeva, J. (1980) Desire in Language. Trans. L. S. Roudiez, Columbia University Press, New York.

[3] Kelly, U. (1990) Who Is Subject to What? ELT Journal, 23, 12-34.

[4] Wenden, W. and Rubin, L. (1987) Learner Strategies in Language Learning. Modern Language Journal, 74, 79-86.

[5] Lightbown, P. and Spada, N. (1993) How Languages Are Learned. Oxford University Press, Oxford.

[6] Zhang, T.B. (2000) Subjectivity Education Theory. Education Science Press.

[7] Wenden, A. (1991) Learner Strategies for Learner Autonomy. Prentice Hall, New York,

[8] Skehan, P. (1988) Individual Differences in Second Language Learning. Routledge Press, London.

[9] Yang, X.W. (1900) Modernization and Subjectivity. Educational Research, No. 7, 40-44.

[10] McDevitt, B. (1997) Learner Autonomy and the Need for Learner Training. Language Learning Journal, 16, 34-39. http://dx.doi.org/10.1080/09571739785200251

[11] Widdowson, H.G. (1990) Linguistics. The University Press, Oxford.

[12] Karajeva, T. (2001) Conditions for Second Language Leaning. Oxford University Press, Oxford.

[13] Little (1990) Where Is the Mind? Constructive and Social Culture Perspectives on Mathematical Development. ELT Journal, 32, 12-16.

\section{Warmly welcome your paper submission to OALib Journal!}

- Publication on a daily basis

- 9 subject areas of science, technology and medicine

- Fair and rigorous peer-review system

- Fast publication process

- Article promotion in various social networking sites (LinkedIn, Facebook, Twitter, etc.)

- Widely-targeted and multidisciplinary audience to read your research

Submit Your Paper Online: Click Here to Submit

Contact Us: service@oalib.com 